\title{
Accommodation structures during kink band evolution; quantitative methods applied to Late Variscan deformation of Portugal
}

\author{
N. Moreira ${ }^{a, b, *}$, R. Dias ${ }^{\text {a,c }}$ \\ ${ }^{a}$ Earth Sciences Institute (ICT) - Pole of the University of Évora, Colégio Luís António Verney, Rua Romão Ramalho, 59, 7000-671, Évora, Portugal \\ ${ }^{\mathrm{b}}$ Instituto de Investigação e Formação Avançada (IIFA), University of Évora, Palácio do Vimioso, Largo Marquês de Marialva, Apart. 94, 7002 - 554, Évora, Portugal \\ ${ }^{\mathrm{c}}$ Departamento de Geociências da Escola de Ciências e Tecnologia da Universidade de Évora - Colégio Luís António Verney, Rua Romão Ramalho, 59, 7000-671, Évora, \\ Portugal
}

\section{A R T I C L E I N F O}

\section{Keywords:}

Kink bands

Deformation mechanisms

Layer parallel shortening

Layer parallel slip

Late Variscan deformation

\begin{abstract}
A B S T R A C T
Kink bands are common in rocks with a strong planar mechanical anisotropy, being generally developed in polydeformed areas during the late stages of deformation, in brittle to brittle-ductile conditions. In the Late Variscan deformation events in the Iberian Massif, several kink band structures were developed in association to the NNE-SSW sinistral strike-slip faults, which are induced by the Laurentia and Gondwana E-W dextral collision on Carboniferous times. Within two metric-scale kink bands, several $2^{\text {nd }}$ order structures are generated in response to internal shortening during layering rotation. The present paper describes the internal geometry and kinematics of these type III fixed hinges kinks bands, discussing their deformation mechanisms. In order to quantify the internal shortening within kink bands, a new graphical method, using simple angular parameters, is proposed. This graphical approach applied to the studied kink bands allows their internal shortening to be quantified; it ranges between 12 and $18 \%$. The genesis of $2^{\text {nd }}$ order structures within kink bands results from the accommodation of the internal layer distortion during kink bands progressive deformation and is controlled by two main deformation processes: layer parallel shortening and layer parallel slip.
\end{abstract}

\section{Introduction}

Kink bands are common in rocks with a strong planar mechanical anisotropy (e.g. bedding, slaty cleavage or schistosity) and are generally developed in low-grade polydeformed areas, under brittle to brittleductile conditions, during the late stages of deformation (Anderson 1964, 1974; Dewey, 1965; Matte, 1969; Suppe 1985; Williams, 1987; Babaie and Speed, 1990; Twiss and Moores, 1992; Sharma and Bhola, 2005; Aller et al., 2020). Although planar anisotropies favour their development, occasionally kink bands are also found in isotropic rocks (Borg and Handin, 1966; Hanmer, 1982; Davies and Pollard, 1986; Williams, 1987; Pachell et al., 2003). These structures could be developed at all scales, from mineralogical (Starkey, 1968; Tchalenko, 1968; Misra and Burg, 2012; Goswami, 2013) to orogenic ones (Collomb and Donzeau, 1974; Goscombe et al., 1994; Suppe et al., 1997; Pachell et al., 2003).

Several approaches have been used in order to understand their genesis, diversity and the deformation mechanisms, ranging from experimental works (Paterson and Weiss, 1962, 1966; Borg and Handin, 1966; Cobbold et al., 1971; Anderson, 1974; Gay and Weiss, 1974; Stewart and Alvarez, 1991; Hanmer et al., 1996 Wadee et al., 2003), field based studies (Anderson, 1964; Matte, 1969; Babaie and Speed, 1990; Stubley, 1990; Sharma and Bhola, 2005; Dunham et al., 2011; Aller et al., 2020) or theoretical studies (Dewey, 1969; Cobbold et al., 1971; Weiss, 1980; Srivastava et al., 1998). Two main models for the genesis of kink bands have resulted by previous studies (e.g. Stewart and Alvarez, 1991; Twiss and Moores, 1992; Sharma and Bhola, 2005; Dunham et al., 2011): the mobile-hinge and the fixed-hinge models. The first model emphasizes the gradual growth of kink bands, either by lateral or rotational migration of their boundaries, while in the fixed-hinge one, the boundaries are fixed and the rotation is restricted to the inner domain of the kink band. In some cases, namely on type III fixed hinges kink bands, the internal rotation of the previous planar anisotropies implies layering length change during the deformation process. Indeed, in the early stages of rotation, the layers inside the kink band will be shortened, while in the latest stages, those anisotropies

\footnotetext{
* Corresponding author. Earth Sciences Institute (ICT) - Pole of the University of Évora, Colégio Luís António Verney, Rua Romão Ramalho, 59, 7000-671, Évora, Portugal.

E-mail address: nafm@uevora.pt (N. Moreira).
} 